\title{
Appropriateness of Liquidity Ratios Model in Predicting Shareholder Wealth of Non-Financial Firms Listed at Nairobi Securities Exchange, Kenya
}

\author{
Obulemire Alex Tom $^{1} \quad$ Dr. Paul Muoki Nzioki ${ }^{2} \quad$ Dr. Koima Kibiwott Joel ${ }^{3}$ \\ 1. University of Kabianga, Department of Accounting and Finance, Kenya \\ 2. Laikipia University, Department of Commerce, Kenya \\ 3. Kabarak University, Department of Computer Science and Bioinformatics, Kenya
}

\begin{abstract}
It is necessary that efforts are put in place by the global investing public to address the ever increasing need to accurately measure performance and financial strength of firms (Pandey, 2013). Analysts of financial statements and investors at the stock market consider a multiplicity of factors and metrics when making decisions on what stocks to invest in. Not much is known on whether change in market prices of securities really reflects results of published financial statements. Whether liquidity ratios models is appropriate for predicting the market prices of shares of firms listed at the Nairobi Securities Exchange (NSE) is the sole question this study endeavours to address. Correlational research design was used. A census of all non financial firms listed at the NSE was conducted and secondary data collected through computation of average rate of change (AROC) in market price of shares, computation of current ratios (CR) and net working capital to total assets (NWCTTA) of non financial firms listed at the NSE for the financial years 2012 to 2016. Panel data was analysed using descriptive statistics, inferential statistics and diagnostic tests. Inferential statistics involved development and testing of predictive ability of liquidity ratios panel data regression model. It was established that announcement of annual financial statements led to a positive mean AROC in market price of shares. Liquidity ratios did not have statistically significant influence on AROC in market price of shares. CR had a statistically insignificant negative effect while NWCTTA ratio had statistically insignificant positive effect on AROC in market price of shares for non financial firms listed at NSE. Also the liquidity ratios model was found not to be statistically significant appropriate in predicting shareholder wealth of non financial firms listed at NSE.
\end{abstract}

Keywords: Average rate of change in market price, liquidity ratios models, current ratio and net working capital to total assets

DOI: $10.7176 /$ RJFA/10-22-14

Publication date: November $30^{\text {th }} 2019$

\section{Introduction}

According to Damodaran (2010) stock price for publicly listed firms is considered by investors to be an observable and real measure of shareholder wealth. Despite this general recognition by investors that stock price is the markets measure of stockholder wealth it is possible for markets to make mistakes in their assessment. Accurate measurement of performance of firms facilitates prediction of wealth attributable to shareholders well in advance instead of relying on market value as reflected by market share prices (Pandey, 2013). To realize this objective investors and financial market analysts engage in financial statement analysis to acquire information that will enable them and or their clients to make informed investment decisions (Irungu \& Gatuhi, 2013). According to Robinson, Greuning, Henry, and Broihahn (2009) financial reports provide information necessary for evaluating firms and establishing how the outcome of evaluation process relates to shareholder value. Due to diverse information needs it is necessary that users of financial statements employ varied analytical techniques to identify information they perceive to be most relevant for a particular decision. Metrics such as financial statement ratios are considered to be a powerful tool of financial statement analysis, capable of removing the size factor and therefore facilitate more relevant comparison. Irungu and Gatuhi, (2013) established that a single indicator of financial performance is not enough to influence market price of shares. Financial statement analysts and investors need to refer to a multiplicity of factors and metrics before making decisions on what shares to buy, retain, or sell-off. Financial indicators of performance such as liquidity, profitability, operational efficiency, leverage, and market performance ratios constitute significant tools of deriving meaning from financial statement information.

\section{Statement of the Problem}

Financial statements users expect external auditors to safeguard their interests by detecting fraud and mismanagement issues in financial reports. Despite this expectation corporate irregularities often erupt immediately unqualified audit reports are released. Unqualified audit reports, market share price, dividends per share and returns on investment relied upon by investors seem to be of minimal use as indicators of financial strength and shareholder wealth. The question that arises is whether change in market prices of securities really 
reflects results of published financial statements. Whether liquidity ratios models is appropriate for predicting the market prices of shares of firms listed at NSE is the sole question this study endeavours to address.

\section{Research Objectives}

The objective of this study was to establish appropriateness of liquidity ratios model in predicting shareholder wealth of non-financial firms listed at Nairobi Securities Exchange.

\section{Research Hypotheses}

$\mathrm{H}_{\mathrm{O} 2}$ : Liquidity ratios model does not have statistically significant appropriateness in predicting shareholder wealth of non-financial firms listed at Nairobi Securities Exchange.

\section{Literature Review}

Several authors have advanced theories and empirical literature that provide basis and explanation regarding ability of liquidity metrics to appropriately predict shareholder wealth of firms expressed in terms of share price.

\subsection{Theoretical Literature Review}

Liquidity ratios focus on cash flows and measure the company's ability to meet its short-term obligations as they fall due (Gitman \& Zutter, 2012; Khotimah \& Mortagi, 2015) and they include current ratio, quick ratio (Edmonds et al, 2016; Arkan, 2016), net working capital to total assets, interval measure (Rose, Westerfield \& Jordan, 2010) and according to Robinson et al, (2009) cash ratio and defensive interval ratio. Liquidity is a function of efficient utilization of assets and how quickly these assets can be converted into cash. The level of liquidity differs from industry-to-industry and is based on anticipated need for funds at any given time. Liquidity ratios reflect company position at any given time and utilize data from ending statement of financial position (Robinson et al, 2009).

\section{Stewardship Theory}

Donaldson and Davis (1991) developed stewardship theory that has its roots anchored in psychology and sociology as a paradigm shift from agency theory with roots in finance and economics that has dominated realms of academic research and corporate governance. Stewardship theory is considered a modern philosophy to corporate governance and a new perspective in trying to understand the relationship between owners and managers of organizations. According to Larson (2013) stewardship theory assumes that corporate executives are stewards of business resources with behaviour and objectives consistent with those of the principals. According to Cossin, Ong, and Coughlan (2015) stewardship theory states that managers will always act as responsible stewards of resources that they control on behalf of their principals. Stewardship is based on the notion of accountability, long term orientation and responsibility for protecting assets of the business overtime.

\subsection{Empirical Literature}

A study by Anwaar (2016) where five independent variables were used with quick ratio being the only financial ratio in the liquidity category revealed that there was an insignificant relationship between quick ratio and stock returns. A study by Arkan (2016) revealed that for industrial and service sector companies there was no significant statistical positive relationship between current ratio and stock price movement, implying that the ability of current ratio to explain stock price trends for listed companies was too poor. The same study results, from investment sector companies, revealed existence of a significant positive correlation between current ratio and stock price trend. Unlike the current study where multiple liquidity category ratios are developed into a liquidity model, Anwaar (2016) only considered quick ratio, while Arkan (2016) only considered current ratio under liquidity ratio category. However a study by Khotimah and Murtaqi (2015) on effect of current ratio, book value to market ratio and total asset turnover on stock price revealed that current ratio had a significant negative effect to stock return.

A study of the role of liquidity in pricing stock returns in Hong Kong stock market by Lam and Tam (2011) yielded results that showed liquidity was an important factor for pricing returns after taking well-documented asset pricing factors into consideration, and also after comparing alternative factor models it was concluded that the liquidity four-factor model (market excess return, size, book-to-market ratio, and liquidity) was the best model for explaining stock returns in the Hong Kong stock market. Lam and Tam (2011) employed the liquidity four-factor model to analyse how liquidity affects stock returns, rather than ratio analysis as is the case in the current study.

Abdulkadir (2016) conducted a study on the effect of leverage, liquidity, firm size, days accounts receivables, days accounts payables on financial performance, measured in terms of returns on equity and return on assets of non-financial firms listed at NSE using panel data over a five year period covering the years 2009 to 2013. In these research regression coefficients were interpreted using the E-views software output and the results revealed that liquidity had a positive effect on returns on assets and returns on equity for non-financial firms in Kenya. Abdulkadir (2016) used E-views software output to analyse the regression equation, and considered returns on assets and returns on equity as dependent variables, unlike the current study that endeavored to use 
stata software in analysis of regression equation and market price of shares as the dependent variable.

\subsection{Critique of Existing Literature}

Research studies conducted to establish the relationship between liquidity category ratios and stock return have mainly used current ratio (Anwaar, 2016) and quick ratio (Arkan, 2016; Khotimah \& Murtagi, 2015) as independent variables. In Kenya an attempt to establish the effect of liquidity on firm performance considered return on assets and return on equity among non-financial firms and not stock market return as is considered in this study.

\subsection{Conceptual Framework Independent Variables}

Dependent Variable

Shareholder Wealth

Market price of shares

Current ratio, Net working capital to total assets

Industry Practice and norms, disclosure level required, corporate strategy and accounting methods

\section{Research Methodology}

Correlational research design was used because it enabled quantitative measures of variables to be studied, without any attempt to influence them and with the objective of determining whether they showed a consistent pattern of relationship. The location of the study was Nairobi, Kenya, because non financial firms listed at the NSE had their operations based in Nairobi. Study population comprised all firms listed at the NSE during the period January 2011 to December 2017. Due to variations in the nature, classification and description of elements disclosed, and scope of disclosure in published financial statements certain categories of ratios for financial sector firms could not be computed. The sampling frame comprised all non financial firms listed at the NSE during the period 2011 to 2017 because some of these firms had their financial years 2012 and 2016 beginning in 2011 and ending in 2017 respectively. Due to small population involved in this study a census of all non financial firms listed at the NSE was conducted. Purposive sampling was used to select firms whose published financial statements were available, signed and their respective dates of announcement clearly determinable for financial years 2012 to 2016. On that basis, 36 NSE listed non financial firms were selected to constituted sample size for this study. The financial years 2012 to 2016 were selected because they were considered to be most recent and capable of providing most current information on financial position and performance of non financial firms listed at the NSE.

\section{Data Collection Instruments and Data collection method}

Secondary data used to carry out this study was obtained from published financial statements and records of daily market prices of shares of non financial firms listed at the NSE. Data collection matrix was used to extract information from published financial statements and from daily market price of shares records for NSE listed non financial firms. Review of daily market prices of shares and published financial statements of NSE listed non financial firms was used as data collection method. The date of financial statement announcement was taken to be the date when the financial statements were approved for issue by the board of directors and was used as a basis for determining the event window period of -20 days to +20 days

\section{Measurement of Variables}

The AROC in market price of shares was established through determination of daily rate of change (ROC) in market price of shares of non financial firms listed at NSE during event window period. According to Dita and Murtagi (2014) the daily ROC was expressed as:

$$
\mathrm{ROC}=\underline{\mathrm{Pt}-\mathrm{Pt}-1}
$$

$$
\text { Pt-1 }
$$

Where: $\mathrm{Pt}=$ Market price of shares during day $\mathrm{t}$, and $\mathrm{Pt}-1=$ Market price of shares during day $\mathrm{t}-1$

AROC in market price of shares was then determined through computation of the geometric mean of daily ROC in market price of shares for each individual non financial firm listed at the NSE. Since it was not possible to compute geometric mean of negative figures adjustments were made to accommodate the negative ROC figures by addition of one to all the ROC figures changing negative figures to positive and deducting one from AROC figure to remove the effect of one initially added. This study used fixed-length event window method where a window period of -20 trading days to +20 trading days was adopted. Data processing involved validation, editing, classification of data, computation of liquidity ratios, computation of daily rate of change in market price and computation of AROC in market price of shares using Microsoft Excel computer application. 
Data was analysed using descriptive statistics, inferential statistics using stata software, and diagnostic test such as cross-sectional dependence, testing for heteroskedasticity and test of normality of distribution. Inferential statistics involved development of liquidity ratios panel data multiple regression model using liquidity ratios current ratio (CR), net working capital to total asset (NWCTA) as independent variables, and evaluation of appropriateness of liquidity ratios panel data multiple regression models in predicting shareholder wealth. Panel data multiple regression analysis models based on Oscar (2007) was developed and expressed as:

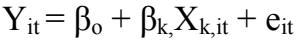

Where: $\mathrm{Y}_{\mathrm{it}}=\mathrm{AROC}$ in market price of shares

$\beta_{\mathrm{o}}=\mathrm{y}$ intercept and constant of the regression equation

$\beta_{\mathrm{k}}=$ coefficient of the independent variable $\mathrm{k}$

$\mathrm{X}_{\mathrm{k}, \mathrm{it}}=$ independent variable $\mathrm{k}$ for firm $\mathrm{i}$ at time $\mathrm{t}$

$i$ - Stands for the non financial firms such that $i=1 \ldots 36$.

$\mathrm{t}$ - Stands for time period and represents such that $\mathrm{t}=1 \ldots .5$

$\mathrm{k}=$ number of independent variables in the liquidity ratios model, such that $\mathrm{k}=1 \ldots 2$ representing $\mathrm{CR}$ ) and NWCTA.

Panel data regression model was most appropriate for this study because according to Oscar (2007) it allows behaviour of entities to be observed over time, controls variables that cannot be observed or measured such as difference in business practices across firms, or variables that change over time but not across entities such as national policy, inflation etc and accounts for individual heterogeneity.

According to Vijayamohanan (2016) the three main types of panel analytic models are: (1) pooled regression (constant coefficients) models, (2) fixed effects models, and (3) random effects models. The Fixed effects and random effects models were used for this study. The pooled regression (constant Coefficient) model was not considered because it assumes that intercepts and slope coefficients are the same over time and for all the cross-sectional units and also variability in industry sectors of firms listed at NSE may lead to non conformity with assumptions of OLS. The fixed and random effects models cater for heterogeneity or individuality among the cross-sectional units by allowing intercepts to change for each cross-sectional unit. To make a choice on which model between fixed effects and random effects model was suitable Hausman test was conducted (Halcoussis, 2005) and the model selected subjected to further interpretation and evaluation. Evaluation of appropriateness of liquidity ratios was conducted using various inferential tests and diagnostic tests. Inferential test included p-values, coefficients of panel regression models and interclass correlation (rho). Diagnostic evaluation was conducted using tests such as Pasaran Cross-Sectional Dependence test, Heteroskedasticity test and Shapiro Wilk test of normality of distribution. Validity was ensured through use of standard formulas that had general acceptance among authorities in financial statement analysis as indicated from literature. Reliability was achieved by ensuring similar ratios were computed using standard formulas generated using Microsoft Excel computer application and using data from published financial statements of NSE listed non financial firms.

\section{Data Analysis and Presentation of Findings \\ 4.1 Descriptive Statistics of Liquidity Ratios}

This section describes the characteristics of CR and NWCTA used in development of liquidity ratios model. The results are presented in Table 4.1.

Table 4.1 Descriptive Statistics of Liquidity Ratios

\begin{tabular}{llllll}
\hline Variable & Mean & Std Deviation & Minimum & Maximum & Observation (N) \\
\hline CR & 2.382025 & 3.143129 & 0.176521 & 20.7939 & 180 \\
NWCTTA & 0.085739 & 0.306960 & -2.444156 & 0.8791 & 180
\end{tabular}

The results in Table 4.1 show that non financial firms listed on NSE had a mean CR of 2.382025 and a standard deviation of 3.143129. The minimum and maximum current ratio observed for these firms was 0.1765206 and 20.7939 respectively for 180 observations. On the other hand the mean NWCTTA ratio was 0.0857385 with a standard deviation of 0.3069597 . The minimum and maximum NWCTTA ratios for the non financial firms considered under this study were -2.444156 and 0.8790651 respectively. The results indicate that all liquidity ratios had means that were positive, with mean CR being greater than unit (i.e. 2.382025), while mean NWCTTA ratio was less than unit (i.e. 0.0857385). This implied that non financial firms listed at the NSE on average had current asset values that were more than two times the value of current liabilities. NSE listed non financial firms had greater ability of meeting their short term obligations as they fall due. According to Robinson et al (2009) a high current ratio implies that there is no reliance on operating cash flow and outside financing to meet short term obligations as they fall due. The findings are in agreement with assertions of Abdulkadir (2016) that non-financial firms quoted at the NSE on average followed a conservative working capital financing policy by maintaining a higher level of current assets in relation to current liabilities leading to high level of working capital. 


\subsection{Descriptive Statistics of Rate of Change in Market Price of Shares}

The mean, standard deviation, number of observations, minimum and maximum average rate of change in market price of shares of non financial firms listed at NSE are presented in Table 4.2 below.

Table 4.2 Descriptive Statistics of Average Rate of Change in Market Price of shares

\begin{tabular}{lrrrcc}
\hline Variable & Mean & Std Deviation & Minimum & Maximum & Observation (N) \\
AROC & 0.002869 & 0.0321816 & -0.062869 & 0.414214 & 180 \\
\hline
\end{tabular}

The results presented in Table 4.2 indicate that the mean average rate of change in market price of shares of non financial firms listed at the NSE, during the event period, was $0.0028692(0.28692 \%)$ and standard deviation of 0.0321816 over the study period of five years from 2012 to 2016 financial years. The minimum average rate of change in market price of shares of firms listed at the NSE was $-0.062869(-6.2869 \%)$, while the maximum was $0.414214(41.4214 \%)$. The positive mean average rate of change in market price of shares is an indication of general increase in the shareholder wealth upon announcement of financial statements results of NSE listed non-financial firms during the financial years 2012 to 2016 . The results for this study were in agreement with the research findings by Chui (2016) published by Dyer and Blair investment Bank, which established that NSE All Share Index (NASI), often used to measure performance of security prices at the NSE, portrayed positive total returns during the period 2008 to 2015.

4.3 Appropriateness of Liquidity Ratios model in predicting shareholder wealth The panel estimates based on fixed effects model were determined and the results presented in Table 4.3 below.

Table 4.3: Panel Estimates of Liquidity Ratios Model Based on Fixed Effects Regression

\begin{tabular}{lllllll}
\hline AROC & Coefficients & Std. Err. & t & $\mathbf{P}>|\mathbf{t}|$ & {$[\mathbf{9 5 \%}$ Conf. Interval] } \\
\hline CR & -0.0008905 & 0.0012024 & -0.74 & 0.460 & -0.0032673 & 0.0014864 \\
NWCTTA & 0.0060523 & 0.0115886 & 0.52 & 0.602 & -0.0168563 & 0.0289608 \\
Constant & 0.0044715 & 0.003552 & 1.26 & 0.210 & -0.0168563 & 0.0289608 \\
\hline Sigma u & 0.01506562 (variance between units) & & & \\
Sigma e & 0.03244441 (Variance within units) & & & \\
rho & 0.17737621 (fraction of variance due to u_i) & & & \\
\end{tabular}

Table 4.5 shows Hausman test result of $p=0.0184$ that was lower than 0.05 set for this study leading to rejection of null test hypothesis that random effects model was suitable estimation method and instead alternative test hypothesis that fixed effects model was suitable estimation method for evaluating appropriateness of liquidity ratios model in predicting shareholder wealth of NSE listed non financial firms was accepted and subjected to interpretation and further evaluation. The fixed effects regression model showed intraclass correlation coefficient (rho) of $17.74 \%$ (rho $=0.17737621$ ) which implied that $17.74 \%$ of the total variance of AROC in the market price of shares was due to differences across panels. Intraclass correlation coefficient which is an indication of how strongly units in the same group (firm) resembled each other implied that an intraclass correlation coefficient of $17.74 \%$ was an indication of low level of serial dependence.

The t-values in Table 4.3 were used to test the hypothesis that each coefficient was not different from zero. Since all the $\mathrm{t}$-values turned out to be less than 1.96 (i.e. $\mathrm{CR} ; \mathrm{t}=-0.74$ and NWCTTA; $\mathrm{t}=0.52$ ) null test hypothesis was not rejected and all liquidity ratios were found not to have significant influence on AROC in market price of shares listed at the NSE. This was also supported by the fact that $\mathrm{p}$ values for all the liquidity ratios were greater than 0.05 (i.e. CR; $p=0.460$ and NWCTTA; $p=0.602$ ) set for this study. Oscar (2007) indicated that the higher the t-value the higher the relevance of an independent variable in influencing the dependent variable.

The liquidity ratio $\mathrm{CR}$ had a statistically insignificant negative effect on AROC in market price of shares of non financial firms listed at the NSE as indicated by its coefficient value of -0.0008905 and $p=0.460$. On the other hand NWCTTA ratio had statistically insignificant positive effect on AROC in market price of shares of non financial firms listed at the NSE as reflected by the coefficient value of 0.0060523 and $p=0.602$. The coefficient of the liquidity ratio CR implied that for every additional unit of AROC in market price of shares of non financial firms listed at the NSE, the estimated average effect of CR on AROC increased by 0.0044715 0.0008905 units when NWCTTA was held constant in the liquidity ratios model. Also for every additional unit of AROC in market price of shares of non financial firms the estimated average effect of NWCTTA was $0.0044715+0.0060523$ units when $\mathrm{CR}$ was held constant in the liquidity ratios model. Based on the corresponding $p$ values for liquidity ratios (ie CR; $p=0.460$ and NWCTTA; $p=0.602$ ) it was established that none of the liquidity ratios had statistically significant influence on AROC in market price of shares of non financial firms listed at the NSE. A study conducted by Khotimah and Murtaqi (2015) established that current ratio had a statistically significant negative effect to stock return. The assertions of Khotimah and Murtaqi (2015) were therefore partly in agreement with the findings of this study.

The panel estimates of liquidity ratios model for predicting shareholder wealth based on random effects regression were determined and the results presented in Table 4.4 below. 
Table 4.4: Panel Estimates of Liquidity Ratios Model Based on Random Effects Regression

\begin{tabular}{lllllll}
\hline AROC1 & Coefficients & Std. Err. & $\mathbf{z}$ & $\mathbf{P}>|\mathbf{z}|$ & \multicolumn{1}{c}{ [95\% Conf. Interval] } \\
\hline CR & 0.001367 & 0.0008654 & 1.58 & 0.114 & -0.0003292 & 0.0030632 \\
NWCTTA & 0.0044482 & 0.0088617 & 0.50 & 0.616 & -0.0129203 & 0.0218168 \\
Constant & -0.0007684 & 0.0030001 & -0.26 & 0.798 & -0.0066485 & 0.0051118 \\
\hline
\end{tabular}

Sigma u 0

Sigma e $\quad 0.03244441$

rho $\quad 0$ (fraction of variance due to $\mathrm{u} \_\mathrm{i}$ )

Results in Table 4.5 on Hausman test gave rise to $p=0.0184$ that was lower than 0.05 leading to rejection of null test hypothesis that random effects model was suitable estimation method. The random effects model was therefore not subjected to further interpretation and evaluation. The Hausman test was conducted to determine which one among random effects model or fixed effects model was most suitable estimation method and results obtained presented in Table 4.15.

Table 4.5: Hausman Test on Suitability of Fixed Effects or Random Effects Model for Evaluating Liquidity Ratios Model

\begin{tabular}{llll}
\hline Test Summary & Chi-Sq. Statistic & Chi-Square d.f. & Probability \\
\hline Cross-section random & 7.99 & 2 & 0.0184 \\
\hline
\end{tabular}

The results in Table 4.5 show that the Chi-square test statistic was 7.99 with a p-value of 0.0184 which was significant at 5 percent level of significance. A significant Hausman statistic meant that null test hypothesis that random effects model was suitable estimation method be rejected in favour of alternative test hypothesis that fixed effects model was suitable estimation method for evaluating appropriateness of liquidity ratios model in predicting shareholder wealth of non-financial firms listed at NSE. The fixed effects model was therefore considered to be suitable estimation method for evaluating appropriateness of liquidity ratios model in predicting shareholder wealth of non financial firms listed at the NSE and was therefore utilized for further empirical evaluation and interpretation. The findings are in agreement with the assertions of Oscar (2007) and Abdulkadir (2016). According to Oscar (2007) the fixed effects model controls for all time invariant differences between individuals and as a result the estimated coefficients of the fixed effects model cannot be biased because of omitted time invariant characteristics. Fixed effects model removes the effect of those time invariant characteristics, such as business practice of the firm, and as a result the net effect of the predictors on the outcome variable is assessed. Further Abdulkadir (2016) indicated that fixed effects model takes care of the unique attributes of individuals that are not the result of random variations and do not vary across time.

The overall appropriateness of liquidity ratios model in predicting shareholder wealth of non financial firms listed at the NSE was determined and the results obtained presented in Table 4.6 below.

Table 4.6: Overall Appropriateness of liquidity ratios model in predicting shareholder wealth

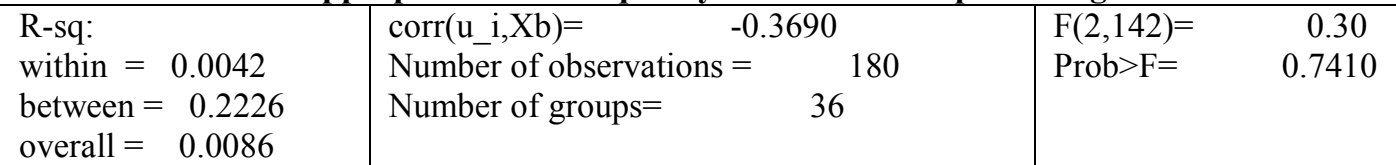

Table 4.6 above provides information on the overall appropriateness of liquidity ratios model in predicting shareholder wealth. The p-value of 0.7410 was used to evaluate the null test hypothesis that all coefficients of liquidity ratios model were zero against alternative hypothesis that at least one of the coefficients was not zero. Consequently it led to the decision that all the coefficients of the liquidity ratios model were zero meaning that investors at the NSE did not utilize information provided by liquidity ratios, CR and NWCTTA, to predict changes in AROC in market price of shares of non financial firms listed at the NSE. Therefore, it was evident that the liquidity ratios model was not statistically significant appropriate for predicting shareholder wealth of non-financial firms listed at NSE. To further support the outcome of inappropriateness of liquidity ratios model in predicting shareholder wealth of non-financial firms listed at NSE was the value corr $(\mathrm{u}$ i $\mathrm{i}, \mathrm{Xb})=-0.3690$ that meant that the errors $u$ were correlated with the regressors in the fixed effects model of liquidity ratios. Also since Prob $>F=0.7410$ was found to be greater than 0.05 , it meant that liquidity ratios model was not appropriate in predicting shareholder wealth of non-financial firms listed at NSE. This findings were in agreement with Oscar (2007) who asserted that Prob $>\mathrm{F}<0.05$ was an indication that a model was appropriate, since it was a test for establishing whether all the coefficients in a model were different than zero.

\subsection{Diagnostic Test for Liquidity Ratios Model}

Testing for Cross-Sectional Dependence:- Pasaran cross-sectional dependence test was used to test whether the residuals are correlated across entities. The null test hypothesis was that residuals across non financial firms listed at the NSE were not correlated. The results obtained indicated that Pasaran's test of cross sectional independence $=1.677$ and $\mathrm{P}=0.0935$ that was more than the critical value of 0.05 set for this study. The null 
hypothesis was therefore not rejected leading to the decision that there was no cross sectional dependence or residuals were not correlated among non financial firms listed at the NSE.

Testing for Heteroskedasticity:- The test for heteroskedasticity is available for the fixed effects model (Oscar, 2007). The null test hypothesis was that there was homoskedasticity or variances of the error term were constant. The test resulted in $p=0.001$ which was less than the critical value of 0.05 . The null test hypothesis was therefore not accepted leading to the decision that there was presence of heteroskedasticity or variances of the error term were not constant.

Diagnostic Test of Normality of Distribution:- In order to establish whether data obtained for the dependent and independent variables was normally distributed the Shapiro-Wilk test was conducted and the results obtained presented in Table 4.7 below.

Table 4.7: Shapiro Wilk Test of Normality of Distribution

\begin{tabular}{llllll}
\hline Variable & Observations & W & V & Z & Prob $>\mathbf{Z}$ \\
\hline AROC & 180 & 0.20805 & 107.819 & 10.711 & 0.00001 \\
CR & 180 & 0.58228 & 56.871 & 9.248 & 0.00001 \\
NWCTTA & 180 & 0.78984 & 28.612 & 7.675 & 0.00001 \\
\hline
\end{tabular}

The results in Table 4.37 above show that the dependent variable AROC in market price of shares and the independent variables CR and NWCTTA were not normally distributed since their $\mathrm{p}$ values were less than 0.05 .

\section{Conclusions}

Announcement of annual financial statements led to a positive mean average rate of change (AROC) in market price of shares. The fixed effects model was found to be suitable for evaluating appropriateness of liquidity ratios model. Liquidity ratios did not have statistically significant influence on AROC in market price of shares and therefore information provided by the liquidity ratios model had no statistically significant influence on choice of investment opportunities among shareholders of NSE listed non financial firms. Liquidity ratios model was not statistically significant appropriate in predicting shareholder wealth of non financial firms listed at the NSE.

\section{Policy Recommendations}

Investor education on potential of liquidity ratios in assessing shareholder wealth of non financial firms listed at the NSE, to current and potential shareholders, in form of seminars and bulletins should be provided. This will enable investors to utilize multiple analytical techniques to make investment decisions.

\section{Recommendations for further research}

Research on effect of liquidity ratios model on market price of shares for each of the industry sectors of firms listed at the NSE. Such a study will assist to avoid the variability associated with different industry sectors of firms listed at the NSE.

\section{References}

Abdulkadir, S. A. B. (2016). The effect of leverage, liquidity, and firm size on financial performance of listed non-financial firms in Kenya. Unpublished doctor of philosophy thesis, Jomo Kenyatta University of Agriculture and Technology

Anwaar, M. (2016). Impact of firms' performance on stock returns: Evidence from listed companies of FTSE100 index london, UK. Global journal of management and business research: Accounting and auditing 16(1), 31-39.

Arkan, T. (2016). The importance of financial ratios in predicting stock price trends: A Case Study in Emerging Markets. Finanse, Rynki Finansowe, Ubezpieczenia, 1(79), 13-26.

Chui, E. (2016). Dyer and Blair investment Bank: Nairobi Securities Exchange, 2008 - 2016. Available online at dyerandblaironline.com/research.

Cossin, D., Ong, H.B., \& Coughlan, S. (2015) Stewardship: Fostering responsible long- term wealth creation, IMD Global Board Center. Available at www.imd.org/boardcenter.

Damodaran, A. (2010). Corporate finance: Theory and practice ( $2^{\text {nd }}$ ed). New Delhi, India: Wiley India (P) ltd.

Dita, A.H. \& Murtaqi, I. (2014). The effect of net profit margin, price to book value, and debt to equity ratio to stock return in the Indonesian consumer goods industry. Journal of Business and Management 3(3), 305 315.

Donaldson, L. \& Davis, J. H. (1991). Stewardship theory or agency theory: CEO governance and shareholder returns. Australian Journal of Management, 16(1), 49-65.

Edmonds, P.E., Edmonds, C.T., Olds, P.R. \& McNair, F.M. (2016). Fundamental Financial Accounting Concepts (8th ed). 2 Penn Plaza, New York: McGraw- Hill Global Education Holdings LLC.

Gitman, L., \& Zutter, C. J. (2012). Principles of managerial finance. Harlow: Pearson Education Limited.

Halcoussis, D. (2005). Understanding econometrics. Ohio USA: Thomson South-Western.

Hausward, H.B.R. (2003). Event studies: assessing the market impact of corporate policy. Korod School of 
Business, American University.

Irungu, M. P. and Gatuhi K. S. (2013). Effect of financial performance indicators on market price of shares in commercial banks of kenya. International Journal of Management \& Business Studies, 3(3), 57-60.

Khotimah, K. and Mortagi, I. (2015). The fundamental analysis of Indonesian stock return: Case study of listed public companies in sub - sector food and beverage for the period 2003 - 2012. Journal of business and management, 4(1), 95-104.

Lam, K. S. K. and Tam, L. H. K. (2011). Liquidity and assets pricing: Evidence from the Hong kong stock market. Journal of banking \& finance, 35 (9), 1-14.

Larson, L.S. (2013). Stewardship theory, stakeholder theory and convergence. Available at https://stephenlarsonessays.files.wordpress.com.

Oscar, T.R. (2007). Panel data analysis fixed and random effects using stata (v.4.2), Princeton University. Retrieved from www.princeton.edu

Pandey, I.M. (2013). Financial management $\left(10^{\text {th }}\right.$ ed). New Delhi, India: Vikas Publishing House.

Robinson, T.R, Greuning, H.V., Henry, E., \& Broihahn M.A, (2009). International financial statement analysis. Hoboken, New Jersey: John Wiley \& Sons, Inc.

Rose, A.S., Westerfield, W.R. \& Jordan, D.B. (2010) Fundamendals of Corporate Finance $\left(9^{\text {th }}\right.$ Ed). Boston Burr Ridge: McGraw-Hill/Irwin.

Vijayamohanan, P., N. (2016). Panel Data Analysis with Stata Part 1: Fixed Effects and Random Effects Models. MPRA Paper No. 76869. Retrieved from https://mpra.ub.uni- uenchen.de/76869 